\title{
Plasma progesterone concentrations and length of the first spontaneous oestrous cycle in pubertal rats
}

\author{
H. Tomogane and A. Yokoyama \\ Department of Animal Science, School of Agriculture, Nagoya University, Chikusa, Nagoya 464-01, \\ Japan
}

\begin{abstract}
Summary. The length of the first spontaneous oestrous cycle in pubertal WistarImamichi strain rats determined by vaginal smears varied from 5 to 18 days. The variation was ascribed to the period (3-16 days) of the stage of vaginal smears consisting of leucocytic cells ( $\mathrm{L}$ stage). Plasma progesterone concentration and the decidual reaction in the uterus were used as indicators of the function of the corpus luteum and the $\mathrm{L}$ stage period was categorized as short, lasting for 3-6 days (average 4 days) with non-functional corpora lutea, or long, lasting 9-16 days (average 12 days) and with functional corpora lutea. Rats with the long $\mathrm{L}$ stage showed nocturnal and diurnal prolactin surges, but no daily changes in prolactin values were observed in rats with a short L stage. Daily changes in prolactin concentrations were maintained by the administration of progesterone in rats ovariectomized on Day 6 of the L stage. Plasma progesterone values on Day 6 of the $\mathrm{L}$ stage decreased with ergocornine treatment on Days 4 and 5 of the $\mathrm{L}$ stage and administration of bovine prolactin restored the level. These results indicate that the $L$ stage observed in the first oestrous cycle is maintained by a positive feedback relation between progesterone and prolactin secretions.
\end{abstract}

Keywords: progesterone; prolactin; oestrous cycle; puberty; rat

\section{Introduction}

The first ovulation in almost all rats occurs on the day of vaginal opening or the following day and the first oestrous cycle of variable length follows (Everett, 1961; Meijs-Roelofs et al., 1975; Osman \& Meijs-Roelofs, 1976; Sarkar \& Fink, 1979; Ramaley, 1979; Pau \& Milner, 1982). Animals establish a regular 4- or 5-day oestrous cycle under a controlled light-dark cycle (12 h light:12 h dark (12L:12D) or 14L:10D) after repeating several irregular cycles (Everett, 1961; Hoffmann, 1973; Rivest et al., 1985). Plasma concentrations of progesterone in the oestrous cycle differ between rats with 4- or 5-day oestrous cycles and the length of the cycle can be determined by progesterone values at dioestrus (van der Schoot \& de Greef, 1976; Nequin et al., 1979; Boehm et al., 1984; Kaneko et al., 1986). Variation in the length of the first spontaneous oestrous cycle in pubertal rats may therefore relate to the concentrations of plasma progesterone during the dioestrous stage as in adult cyclic rats.

The presence of prolactin keeps the plasma value of progesterone high in the morning of the second day of dioestrus (Geiger et al., 1988), and Tomogane \& Yokoyama (1989) have indicated that the mechanism controlling the nocturnal surge of prolactin is more sensitive to progesterone in peripubertal rats than in adult rats. A very small amount of progesterone secreted from corpora lutea formed after the first spontaneous ovulation would promote the surge-like prolactin secretion which stimulates and sustains luteal function. The aim of the present experiments was to elucidate the mechanism(s) determining the length of the first spontaneous oestrous cycle with reference to: (1) the relationship between the length of the first oestrous cycle and concentrations of plasma 
progesterone; (2) effects of traumatization of the uterine horns on the length of the first oestrous cycle; and (3) a possible correlation between plasma progesterone and prolactin concentrations.

\section{Materials and Methods}

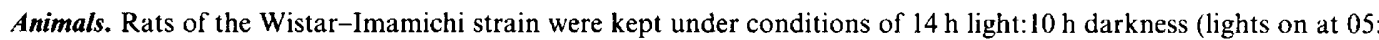
$00 \mathrm{~h}$ ) and $24 \pm 2{ }^{\circ} \mathrm{C}$ with food (CE 2, Nihon CLEA, Yokohama, Japan) and water ad libitum. Adult animals were purchased from Dohhan Ken, Ltd (Saitama, Japan). Pubertal animals used were bred in our laboratory. The day of birth was designated Day 0 of age and litter size was adjusted to 8 on Day 1. The young were weaned on Day 21. After weaning, 3-4 animals were housed in a plastic cage $(30 \times 23 \times 17 \mathrm{~cm})$ and adult rats were kept in individual cages. Vaginal opening was checked every morning in pubertal animals after Day 28 . Animals were weighed on the day of vaginal opening and vaginal smears taken by lavage with physiological saline $(0.15 \mathrm{M}-\mathrm{NaCl})$ were examined every morning throughout the experiment. Pseudopregnancy was induced by mating with a vasectomized rat at the prooestrous or oestrous stage of the cycle in pubertal and 4-day cyclic adult rats. The period showing leucocytic vaginal smears was designated the L stage and Day $\mathrm{l}$ of the $\mathrm{L}$ stage was the first day on which leucocytic vaginal smears appeared after vaginal cornification.

Experiment 1. Blood samples (about $0.2 \mathrm{ml}$ ) for measuring plasma progesterone were collected once between 10:00 and 12:00 h on Days 3, 6 or 9 of the $L$ stage during the oestrous cycle from the jugular vein under light ether anaesthesia. Vaginal smears were checked every morning until the day on which cornified epthelial cells appeared.

Experiment 2. Traumatization of uterine horns was performed by the method described by DeFeo (1963) with a slight modification. During the morning of Day 3 of the $\mathbf{L}$ stage, uterine horns were exposed through a midventral abdominal incision under ether anaesthesia. A suture needle with a silk thread (o.d. $0.2 \mathrm{~mm}$ ) was introduced into the uterine lumen. The thread was looped through the antimesometrial surface, moved several times back and forth and tied loosely (length, 4-5 mm) on the outside of the uterus: 6 loops were made at appropriate intervals on each uterine horn. Exposure of the uterus for $1 \mathrm{~min}$ served as the sham operation. Some of the sham-operated and traumatized animals were decapitated 6 days after the traumatization and the trunk blood was collected for measurement of plasma progesterone. The uterine horns were dissected free of fat and weighed to the nearest $0.5 \mathrm{mg}$. Vaginal smears were taken until cornified epithelial cells appeared in the smear.

Experiment 3. Animals were decapitated at $05: 00 \mathrm{~h}, 12: 00 \mathrm{~h}$ and 18:00 h on Days 6 or 9 of the $\mathrm{L}$ stage of the first oestrous cycle in pubertal rats and trunk blood was collected for assay of plasma progesterone and prolactin. In addition, the following 2 groups were provided. In Group 1, Silastic tubes (Dow Corning, Midland, MI, USA; i.d. $2.64 \mathrm{~mm}$, o.d. $4.88 \mathrm{~mm}$, length $10 \mathrm{~cm}$ ) containing progesterone were inserted subcutaneously immediately after the ovariectomy performed on Day 6 of the L stage. In Group 2, rats were injected subcutaneously with ergocornine $(0.5 \mathrm{mg} / 0.1 \mathrm{mi}$; Sandoz Ltd, Basel, Switzerland) at $12: 00 \mathrm{~h}$ on Days 4 and 5 of the L stage. Prolactin $(0.2 \mathrm{mg} \mathrm{NIH}-$ PRL-B-4/0.1 ml, 13.0 i.u/mg) was injected at $09: 00 \mathrm{~h}$ and 18:00 h on Days 4 and 5 of the L stage and at 09:00 h on Day 6 of the L stage. Animals injected with the vehicle (saline) at corresponding times served as controls.

Blood samples (about $0 \cdot 2 \mathrm{ml}$ ) were collected once between 10:00 and 12:00 h under ether anaesthesia from the jugular vein of each animal showing leucocytic vaginal smears until Day 6 of the $L$ stage of the first oestrous cycle. After blood collection, vaginal smears were recorded every morning until the smears became cornified.

Hormone assays. The plasma was separated by immediate centrifugation $\left(4^{\circ} \mathrm{C}\right.$ and $1500 \mathrm{~g}$ for $\left.10 \mathrm{~min}\right)$ after collection and stored at $-20^{\circ} \mathrm{C}$ until progesterone or prolactin assay by RIA. Prolactin was measured by using the NIADDK RIA rat prolactin kit (rPRL-I-5, anti-rPRL-S-9, rPRL-P-2). Each sample $(25 \mu \mathrm{l})$ was measured in duplicate. The intra-assay coefficient of variation was $7.5 \%$ at the level of $0.362 \mathrm{ng} /$ tube. The minimum detectable level was $0.031 \mathrm{ng} /$ tube. For assay of progesterone, plasma was extracted first with diethyl ether and further chromatographic separation was not performed. The RIA used $\left[1,2,4,7-{ }^{3} \mathrm{H}(\mathrm{N})\right]$ progesterone (sp.act. $96 \cdot 5 \mathrm{Ci} / \mathrm{mmol}$ : New England Nuclear, Boston, MA, USA), unlabelled progesterone (Sigma Chemical Co., St Louis, MO, USA) and the antiserum against progesterone-3-oxime-BSA (Teikoku Horm. Mfg Co., Kawasaki, Japan). Assays were performed in duplicate on 2.5 or $50 \mu \mathrm{l}$ plasma samples for expected high and low hormone levels. The intra- and inter-assay coefficients of variation were $8 \%$ at the level of $72.5 \mathrm{pg} /$ tube and $12 \%$ at the level of $75.4 \mathrm{pg} /$ tube, respectively. The lowest detectable level was $12.5 \mathrm{pg} /$ tube.

Statistical analyses. Results are expressed as the mean \pm s.e.m. The difference between means of more than two groups was analysed by Duncan's new multiple range test, and Student's $t$ test or the Cochran-Cox test was used for testing the difference between the two means. Significance was achieved when $P<0.05$.

\section{Results}

\section{Experiment 1: relationship between the duration of the first oestrous cycle and the concentration of plasma progesterone}

The duration of the oestrous stage of the vaginal smears of the first spontaneous oestrous cycle was less than 2 days in about $90 \%$ of 41 animals used while the $\mathrm{L}$ stage varied from 3 to 16 days. 
The high distribution of the L-stage period was observed at $3(9 / 41$ animals) and 11 days (7/41) of L-stage. Overall mean of the length of the $\mathrm{L}$ stage was $8.9 \pm 0.7$ days $(\mathrm{N}=41)$.

The plasma concentration of progesterone on Day 3 of the $\mathrm{L}$ stage was significantly low in 13 out of 16 rats with an $L$ stage of $<6$ days compared with animals exhibiting an $L$ stage of $>9$ days $(P<0.05$, Fig. 1). In 3 out of 16 rats with an $\mathrm{L}$ stage of $<6$ days the progesterone concentration was significantly higher than in the remaining 13 rats $(P<0.05$, Fig. 1$)$. In rats with an $\mathrm{L}$ stage of $>9$ days, plasma values of progesterone peaked on Day 6 and then decreased significantly on Day $9(P<0 \cdot 05$, Fig. 1$)$.
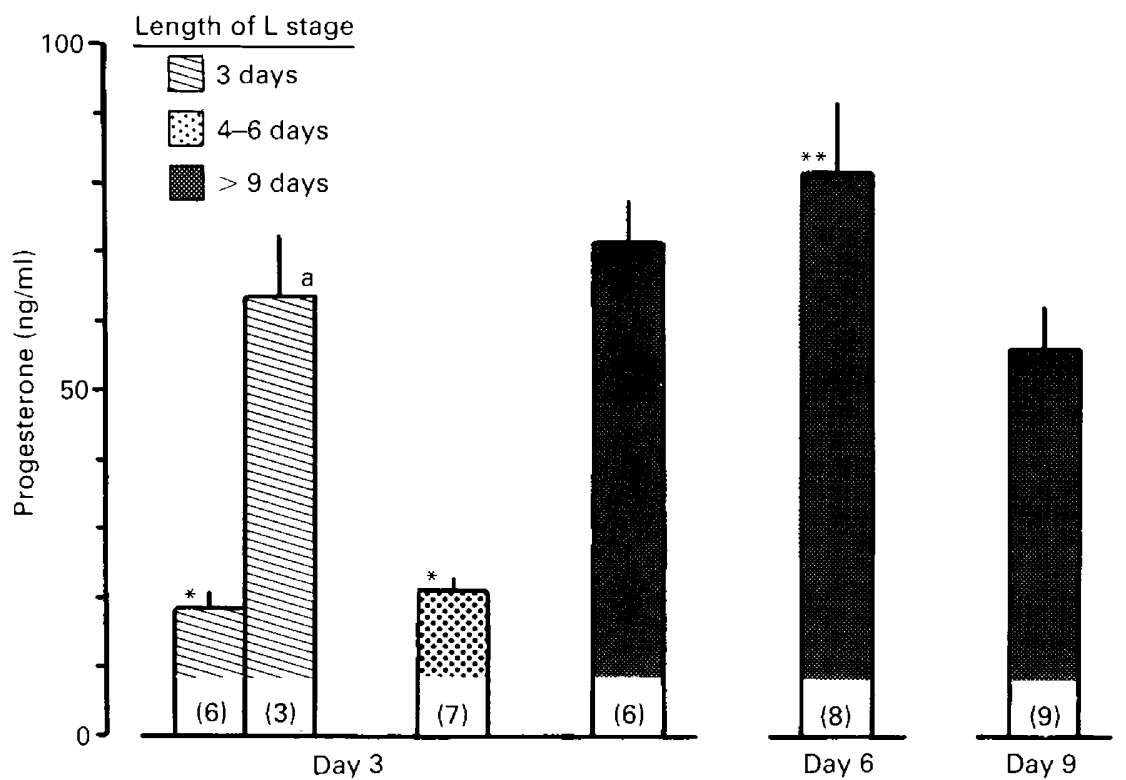

Fig. 1. Concentrations of plasma progesterone on Days 3,6 and 9 of the stage showing leucocytic vaginal smears ( $\mathrm{L}$ stage) in the first spontaneous oestrous cycle in pubertal rats. Values are means \pm s.e.m. Numbers in each bar represent the numbers of animals used. a, $P<0.05$ compared with the value for other rats with an L stage of 3 days (Duncan's test). * Significantly different $(P<0.05)$ from the highest value on Day 3 of the $\mathrm{L}$ stage (Duncan's test). ${ }^{* *}$ Significantly different $(P<0.05)$ from the value on Day 9 of the L stage in rats with dioestrus for $>9$ days (Duncan's test).

\section{Experiment 2: effect of uterine horn traumatization}

In traumatized rats in which the duration of the $\mathrm{L}$ stage was $<6$ days, no deciduoma was formed and no effect of traumatization on the duration appeared (sham-operated: $5 \cdot 2 \pm 0 \cdot 3$ days, $\mathrm{N}=7$; traumatized: $5 \cdot 1 \pm 0 \cdot 1$ days, $\mathrm{N}=6$ ).

In the first oestrous cycle in pubertal rats, the traumatization extended the duration of the $\mathrm{L}$ stage. It continued for more than 9 days and the duration $(14.4 \pm 0.5$ days, $\mathrm{N}=5)$ was significantly longer than that in the sham-operated rats $(11.5 \pm 0.6$ days, $\mathrm{N}=12)(P<0.05$, Student's $t$ test). In pseudopregnant adult rats, a similar effect of traumatization was observed (sham-operated $12.8 \pm 0.7$ days, $N=7$; traumatized: $17.7 \pm 0.7$ days, $N=7)(P<0.05$, Student's $t$ test $)$.

The traumatized pubertal rats showed leucocytic vaginal smears continuously for at least 9 days until the time of autopsy. The weight of the uterus and the concentration of plasma progesterone were significantly higher than those in sham-operated rats $(P<0.05$, Table 1$)$. The effect of the traumatization observed in pubertal rats was similar to that in pseudopregnant adult rats. 
Table 1. Effects of uterine trauma on Day 3 of the stage showing leucocytic vaginal smears (L stage) on the concentration of plasma progesterone and the uterine weight on Day 9 of the $\mathrm{L}$ stage in the first oestrous cycle in pubertal and pseudopregnant adult rats

\begin{tabular}{|c|c|c|c|c|}
\hline & \multicolumn{2}{|c|}{$\begin{array}{l}\text { Pubertal rats showing } \\
\text { first oestrous cycle }\end{array}$} & \multicolumn{2}{|c|}{$\begin{array}{l}\text { Pseudopregnant } \\
\text { adult rats }\end{array}$} \\
\hline & Sham-operated & Traumatized & Sham-operated & Traumatized \\
\hline No. of animals & 5 & 6 & 5 & 6 \\
\hline Uterine wt (mg) & $188 \cdot 4 \pm 27 \cdot 6$ & $1363 \cdot 9 \pm 205 \cdot 6^{a}$ & $323.7 \pm 36.8$ & $1437 \cdot 6 \pm 134 \cdot 4^{a}$ \\
\hline Progesterone & $67 \cdot 3 \pm 3 \cdot 2$ & $82 \cdot 2 \pm 4 \cdot 0^{b}$ & $76.4 \pm 4.6$ & $97 \cdot 4 \pm 4.6^{b}$ \\
\hline
\end{tabular}

Values are mean \pm s.e.m.

a, b: $P<0.05$ compared with the value of sham-operated animals (a, Cochran-Cox test: b, Student's $t$ test).

\section{Experiment 3: relationship between plasma concentrations of progesterone and prolactin}

Since plasma progesterone concentrations of animals in which dioestrus ended within 6 days were $<30 \mathrm{ng} / \mathrm{ml}$ plasma, $30 \mathrm{ng} / \mathrm{ml}$ was regarded as the basal progesterone level. In animals with progesterone values higher than the basal level on Day 6 of the $L$ stage, daily changes in plasma prolactin concentrations were demonstrated: the value at $05: 00 \mathrm{~h}$ was significantly higher than at other times of the day $(P<0.05$, Fig. 2). Values remained low during the day in animals in which progesterone concentrations were below the basal level (Fig. 2).

On Day 9 of the $L$ stage, prolactin values were significantly reduced in intact animals at 12:00 $\mathrm{h}$ (Fig. 2).

Ovariectomy on Day 6 of the L stage decreased the plasma prolactin to basal levels and no peak was observed at $05: 00$ or 18:00 h on Day 9 of the $\mathrm{L}$ stage (Fig. 2). In ovariectomized rats with progesterone implants, the prolactin profile was similar to that in intact rats (Fig. 2).

The concentration of plasma progesterone $(11.3 \pm 1.7 \mathrm{ng} / \mathrm{ml}$ plasma, $\mathrm{N}=7)$ significantly decreased in rats treated with ergocornine $(P<0.05$, Cochran-Cox test $)$ from the control value $(58.9 \pm 6.9 \mathrm{ng} / \mathrm{ml}$ plasma, $\mathrm{N}=8)$ and the administration of bovine prolactin restored the progesterone level $(48 \cdot 1 \pm 12 \cdot 1 \mathrm{ng} / \mathrm{ml}$ plasma, $\mathrm{N}=7)$. However, the duration of the $\mathrm{L}$ stage shortened by the ergocornine treatment $(6.7 \pm 0.4$ days, $N=7$ compared with $12.6 \pm 0.7$ days, $N=8$ ) was not affected by treatment with bovine prolactin $(7 \cdot 7 \pm 0.5$ days, $\mathrm{N}=7)$.

\section{Discussion}

The present results indicate that the variation in the length of vaginal cycle in the first spontaneous oestrous cycle is mainly due to the length of the stage of leucocytic vaginal smears and that the cycle can be classified into short and long cycles. The length of the short and long $L$ stage was $<6$ days or $>9$ days, respectively. Similarity of the hormonal conditions of the long cycle to pseudopregnancy was inferred from the following findings. The mean of the long L-stage period $(12.2 \pm 0.3$ days, $\mathbf{N}=25$ ) and the pattern of plasma progesterone values during this period (Fig. 1) were very similar to the duration and the pattern during pseudopregnancy. The positive decidual cell reaction and effects of the deciduoma on the function of corpora lutea reported for pseudopregnant animals (Nuti et al., 1975; Rothchild, 1981) were also observed in the rats showing the long cycle (Table 1). The nocturnal surge of prolactin appeared in the long cycle as well as in pseudopregnancy (Fig. 2). The length of the short first oestrous cycle is consistent with the results reported by many workers (Osman \& Meijs-Roelofs, 1976; Meijs-Roelofs et al., 1982; Pau \& Milner, 1982; Rivest et al., 1985).

In the present study, diurnal changes of the plasma prolactin concentration were observed in animals in which the high concentration of plasma progesterone was found on Day 6 of the L stage 

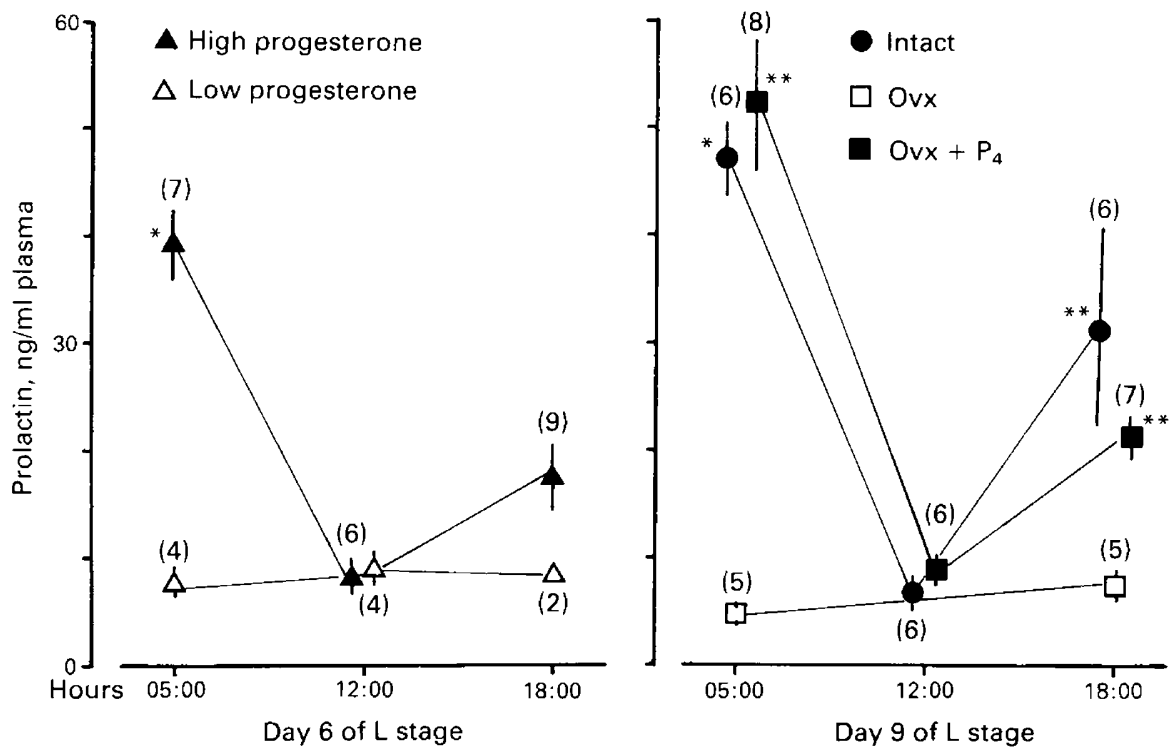

Fig. 2. Changes in concentrations of plasma prolactin on Day 6 or 9 of the stage showing leucocytic vaginal smears ( $\mathrm{L}$ stage) of the first spontaneous oestrous cycle. The rats on Day 6 of the $\mathbf{L}$ stage were considered as 2 groups according to plasma progesterone concentrations: high values $(\Delta)$ were $66 \cdot 2 \pm 6.3 \mathrm{ng} / \mathrm{ml}(\mathrm{N}=22)$ and low values $(\triangle)$ were $22.5 \pm 2.5 \mathrm{ng} / \mathrm{ml}(\mathrm{N}=$ 10). Ovariectomy and subcutaneous insertion of Silastic tubing containing progesterone were performed on Day 6 of the $L$ stage. Values are mean \pm s.e.m. for the numbers of animals indicated, and the concentrations of plasma progesterone were $60 \cdot 3 \pm 6 \cdot 1 \mathrm{ng} / \mathrm{ml}(\mathrm{N}=18)$ for intact rats, $3.6 \pm 0.8 \mathrm{ng} / \mathrm{ml}(\mathrm{N}=10)$ for ovariectomized (Ovx) rats, and $50.0 \pm 3.8 \mathrm{ng} / \mathrm{ml}$ $(\mathrm{N}=20)$ for ovariectomized rats with s.c. progesterone $\left(\mathrm{P}_{4}\right)$ implants. ${ }^{*},{ }^{* *}$ Significantly different $(P<0.05)$ from the value at $12: 00 \mathrm{~h}$ for that group $\left({ }^{*}\right.$, Student's $t$ test; ${ }^{* *}$, Cochran-Cox test).

(Fig. 2). In contrast, in almost all animals with low concentrations of progesterone, prolactin remained at basal levels throughout the experiment (Fig. 2) When the L-stage period continued for more than 9 days, diurnal changes of plasma prolactin appeared in all rats examined (Fig. 2). Ovariectomy on Day 6 of the L stage abolished daily changes of plasma prolactin level and the replacement with progesterone restored the daily change (Fig. 2). These results indicate that diurnal changes of prolactin secretion depend on the circulating level of progesterone in the first spontaneous oestrous cycle as well as in the pseudopregnancy and pregnancy (de Greef \& Zeilmaker, 1978; Voogt, 1980; Takahashi et al., 1980; Gunnet \& Freeman, 1983; Tomogane \& Yokoyama, 1989).

Since the concentrations of plasma progesterone and prolactin were lowered after the treatment with ergocornine (Yokoyama et al., 1972; Tomogane et al., 1975) and this decline was prevented by treatment with bovine prolactin replacement, prolactin plays a role as a luteotrophic factor during the $\mathrm{L}$ stage in the first oestrous cycle, as it does in the oestrous cycle in the adult animal (Boehm et al., 1984), pregnancy and pseudopregnancy (Rothchild, 1981) and lactation (Tomogane et al., 1975). Therefore, the results of the present study indicate that the pseudopregnancy-like long L-stage period in the first spontaneous oestrous cycle is maintained by a positive feedback relationship between progesterone and prolactin secretions.

The concentration of plasma progesterone was about $20 \mathrm{ng} / \mathrm{ml}$ plasma on Day 3 (Fig. 1) and Day 6 (Fig. 2) of the L stage in the rats with the short L-stage period. Although these animals showed no diurnal changes of plasma prolactin (Fig. 2), ergocornine administration on Days 4 and 5 of the $\mathrm{L}$ stage decreased the concentration of plasma progesterone to about half the level in the control rats on Day 6 of the L stage. Therefore, prolactin seems to play a luteotrophic role after 
Day 3 of the $\mathrm{L}$ stage even in rats with a short L stage. Prolactin administered to hypophysectomized adult rats $60 \mathrm{~h}$ after the formation of corpora lutea failed to activate the corpus luteum (Malven, 1969). It is therefore likely that responsiveness to luteotrophic factors of the corpora lutea formed after the first spontaneous ovulation lasts longer than that of corpora lutea formed in the normal cycle of the adult rat.

Since the amount of progesterone required for inducing the prolactin nocturnal surge in ovariectomized peripubertal rats was lower than that in ovariectomized adult rats (Tomogane \& Yokoyama, 1989), a high susceptibility of the mechanism controlling the nocturnal surge of prolactin to progesterone seems to be responsible for inducing the long pseudopregnancy-like dioestrus appearing after the first spontaneous ovulation. Although the concentration of plasma progesterone on Day 3 of the $\mathrm{L}$ stage was the same as in the rats continuing the pseudopregnancy-like dioestrus, there were 3 rats in which the L stage ended within 3 days (Fig. 1). We do not have any explanation of why these 3 rats did not show the long $L$ stage. Incompetence of the mechanism regulating the prolactin surge to progesterone may be a factor, since the nocturnal surge of prolactin was induced by the implantation of Silastic tubing filled with progesterone only when the tube was implanted at a very restricted time of the cycle even in cyclic adult rats (Tomogane \& Yokoyama, 1989).

Progesterone could enhance the sensitivity of rats to stimuli such as taking vaginal smears and those resulting from contact amongst animals or odours associated with housing conditions (Everett, 1963; Lugue \& Castro-Vazquez, 1983). In the present study, 3 or 4 rats were housed together in a cage and vaginal smears were taken daily after vaginal opening. These stimuli may increase the rate of appearance of the long $L$ stage in the first oestrous cycle. Kawaminami \& Takahashi (1987) succeeded in inducing the nocturnal surge of prolactin in rats bearing Silastic tubing containing progesterone without taking vaginal smears. We also found in a preliminary experiment that animals showed the long $L$ stage even when vaginal smearing was stopped for 3 days after vaginal opening.

In conclusion, the formation of the functional corpus luteum is responsible for the variation in the length of the first spontaneous oestrous cycle in pubertal rats and the function of newly formed corpora lutea is maintained by the nocturnal prolactin surge caused by the positive feedback relationship between progesterone and prolactin secretions in the pubertal rat.

We thank Sandoz Ltd, Basel, Switzerland, for supplying ergocornine; and the NIADDK for the rPRL-RIA kit and bovine prolactin.

\section{References}

Boehm, N., Plas-Roser, S. \& Aron, C.I. (1984) Prolactin and the control of cycle length in the female rat. Acta endocr., Copenh. 106, 188-192.

DeFeo, V.J. (1963) Temporal aspect of uterine sensitivity in the pseudopregnant or pregnant rat. Endocrinology 72, 305-315.

de Greef, W.J. \& Zeilmaker, G.H. (1978) Regulation of prolactin secretion during the luteal phase in the rat. Endocrinology 102, 1190-1198.

Everett, J.W. (1961) The female reproductive cycle and its controlling mechanism. In Sex and Internal Secretions, Vol. 1, pp. 497-555. Ed. W. C. Young. Williams and Wilkins, Baltimore.

Everett, J.W. (1963) Pseudopregnancy in the rat from brief treatment with progesterone: effect of isolation. Nature, Lond. 200, 695-696.

Geiger, J.M., Boehm, N. \& Aron, C.I. (1988) Estrous cycle lengthening by pentobarbital in the rat: pro- lactin involvement Acta endocr., Copenh. 118, 199-203.

Gunnet, J.W. \& Freeman, M.E. (1983) The matinginduced release of prolactin: a unique neuroendocrine response. Endocrine Rev. 4, 44-61.

Hoffmann, J.C. (1973) The influence of photoperiod on reproductive functions in female mammals. In $H$ andbook of Physiology, Vol. 2, pp. 57-77. Ed. R. O. Greep. Williams and Wilkins, Baltimore.

Kaneko, S., Sato, N., Sato, K. \& Hashimoto, I. (1986) Changes in plasma progesterone, estradiol, folliclestimulating hormone and luteinizing hormone during diestrus and ovulation in rats with 5-day estrous cycles: effect of antibody against progesterone. Biol. Reprod. 34, 488-494.

Kawaminami, M. \& Takahashi, M. (1987) Induction of daily PRL surges in rats by chronic treatment with progesterone. Endocr. japon 34, 37-44. 
Lugue, E.H. \& Castro-Vazguez, A. (1983) Sensory mechanisms involved in the induction of pseudopregnancy by progesterone: increased sensitivity to stimulation of the pudendal sensory field. Endocrinology 113, 385-390.

Malven, P.V. (1969) Luteotrophic and luteolytic responses to prolactin in hypophysectomized rats. Endocrinology 84, 1124-1229.

Meijs-Roelofs, H.M.A., Uilenbroek, J.Th.J., de Greef, W.J., de Jong, F.H. \& Kramer, P. (1975) Gonadotrophin and steroid levels around the time of first ovulation in the rat. J. Endocr. 67, 275-282.

Meijs-Roelofs, H.M.A., Osman, P. \& Kramer, P. (1982) Ovarian follicular development leading to first ovulation and accompanying gonadotrophin levels as studied in the unilaterally ovariectomized rat. $J$. Endocr. 92, 341-349.

Nequin, L.G., Alvarez, J. \& Schwartz, N.B. (1979) Measurement of serum steroid and gonadotropin levels and uterine and ovarian variables throughout 4 day and 5 day estrous cycles in the rat. Biol. Reprod. 34, 488-494.

Nuti, K.M., Sridharan, B.N. \& Meyer, R.K. (1975) Reproductive biology of PMSG-primed immature female rats. Biol. Reprod. 13, 38-44.

Osman, P. \& Meijs-Roelofs, H.M.A. (1976) Effects of sodium pentobarbitone administration on gonadotrophin release, first ovulation and ovarian morphology in pubertal rats. J. Endocr. 68, 431-437.

Pau, M.-Y. \& Milner, J.A. (1982) Dietary arginine and sexual maturation of the female rat. $J . N u t r .112$, $1834-1842$.

Ramaley, J.A. (1979) Development of gonadotropin regulation in the prepubertal mammal. Biol. Reprod. 20, $1-31$.
Rivest, R.W., Lang, U., Aubert, M.L. \& Sizonenko, P.C. (1985) Daily administration of melatonin delays rat vaginal opening and disrupts the first estrous cycles: evidence that these effects are synchronized by the onset of light. Endocrinology 116, 779-787.

Rothchild, I. (1981) The regulation of mammalian corpus luteum. Recent Prog. Horm. Res. 37, 183-298.

Sarkar, D.K \& Fink, G. (1979) Mechanism of the first spontaneous gonadotrophin surge and that induced by pregnant mare serum and effects of neonatal androgen in rats. $J$. Endocr. 83, 339-354.

Takahashi, M., Murakami, N., Naito, H. \& Suzuki, Y. (1980) Blockade of pseudopregnancy in the rat by treatment with antiprogesterone serum. Biol. Reprod. 22, 423-429.

Tomogane, H. \& Yokoyama, A. (1989) Development of progesterone dependency in the appearance of the nocturnal prolactin surge in immature rats. $J$. Reprod. Fert. 85, 503-509.

Tomogane, H., Ôta, K. \& Yokoyama, A. (1975) Suppression of progesterone secretion in lactating rats by administration of ergocornine and the effect of prolactin replacement. $J$. Endocr. 65, 155-161.

van der Schoot, P. \& de Greef, W.J. (1976) Dioestrous progesterone and pro-oestrous luteinizing hormone in 4- and 5-day cycles of female rats. J. Endocr. 70, 61-68.

Voogt, J.L. (1980) Regulation of nocturnal prolactin surges during pregnancy in the rat. Endocrinology 106, 1670-1676.

Yokoyama, A., Tomogane, H. \& Ôta, K. (1972) Ergocornine blockade of the surge of prolactin at proestrus failed to block ovulation in cycling rats. Proc. Soc. exp. Biol. Med. 140, 169-171.

Received 31 March 1989 